\author{
International Research Journal of Shariah, \\ Muamalat and Islam (IRJSMI) \\ Journal Website: http://irjsmi.com/ \\ eISSN: 2682-8553
}

\title{
THE HISTORICAL CONTRIBUTIONS OF CONTEMPORARY ULAMA BASED ON SECTS: IN PROMOTING ISLAMIC SOCIETY IN NORTHERN NIGERIA
}

\author{
Dr. Munubiyya Sani Jibril ${ }^{1}$, Musa Umar Yakasai $^{2}$, Saddam Abubakar ${ }^{3}$
}

1 Department of Islamic Studies, Federal University Gashua, Yobe State

Email: ayshtj@gmail.com

2 Department of Islamic Studies, Federal University Gashua, Yobe State

Email: musaumaryakasai334@gmail.com

3 Department of Islamic Studies, Federal University Gashua, Yobe State

\section{Article Info:}

\section{Article history:}

Received date: 07.04 .2020

Revised date: 10.06 .2020

Accepted date: 12.06 .2020

Published date: 10.06.2020

\section{To cite this document:}

Munubiyyah. S. J., Musa. U. Y., \& Saddam. A. (2020). The Historical Contributions of Contemporary Ulama Based on Sects: In Promoting Islamic Society in Northern Nigeria. International Research of Shariah, Muamalat and Islam, 2 (4), 70-84.

DOI: $10.35631 /$ IRJSMI.24007.

\begin{abstract}
:
Islam clearly referred to the word of peace justice and equity where the Islam considered every individual as equal in the sight of Allah, and also indicates the must closer in the sight of Him is the most fairness person. However, Allah (SWT) kept sending a messenger from time to time from their kind, to serve as messenger and prophet for conveying the divine messages for guidance. The last and final Message and Messenger, that is the Qur'an and Prophet of Allah, Muhammad (PBUH), the son of Abdullah. Therefore, since there would never be any other messenger, the responsibly for carrying on with that onerous divine duties are vested on the most learned of their times, the Ulama' in setting out an all-encompassing teaching and regulatory framework for achieving optimum relationship between man and his Creator, the entire environment of the Universe and all other creations therein. For this reason, the Ulama been considered at the honorable status of the inheritors of the Messenger of Allah SWT. The paper investigates the enormous contributions of Ulama' and identifies the serious challenges facing the Islam and its society of Northern Nigeria based on varies of understanding mainly arising from the ideological teachings of the overzealous few and sects in disregarding the provisions of the Qur'an and Sunnah such as (Tariqa, Izala, and Salaf) which is considered the main problems of sectarianism, extremism, and disunity, in some cases in Northern Nigeria. The paper employed the comparison method, to analyze the theoretical discussion of the sects. The findings indicate that there is a need to screen the Ulama' of all groups, in establishing a common structure that shall not only unite but will address the yearnings and aspirations of the Ummah and Islam in Northern Nigeria.
\end{abstract}




\section{Introduction}

The Northern Nigeria is been dominated by the Muslims with different sects of Islam, some were Izala deals with the Qur'an and Sunnah and says of the pious predecessors which in order words were related to the Salaf. while the Tarikah is a practice that was considered controversial by the Izala scholars a time with teachings of the Qur'an and Sunnah of the Prophet (SAW). The dominant Islamic community in Northern Nigeria is facing multifarious problems, of several dimensions of insecurity, ignorance, poverty, injustice, and overall underdevelopmental issues. After all, Allah (SWT) in His infinite mercy provided mankind with all provisions and ability to command, the knowledge to explore and exploit the unlimited resources on this universe, which may he require in satisfying all his needs, to fulfill the purpose of his creation. Allah SWT says:

\section{\{And We bestowed upon you all what is in the heaven and on the earth ...\} (Qur'an 45: 13).}

Therefore, there is only one main explanation for this calamity faced by Ummah, and from it there comes only one available solution. Allah says \{Indeed, Allah will not change the condition of people until they change what is in themselves? (Qur'an 13: 11). Departure from the path of Allah SWT by believers is the root cause of their problems, and the solution is to turn back to him with repentance and righteous deeds. The responsibility for guiding the ordinary believer is stated by none other Himself Allah SWT and His Prophet PBUH, who said:

"There are two classes in my Ummah, if they are right the Ummah is set right, if they are wrong the Ummah goes wrong: they are the rulers and the scholars" (Nu'aym, 1405).

The contemporary Ulama' of the North, must be united and act in solidarity without bias, partiality, or prejudice. They must avoid all means of unnecessary dispute, disagreement, argument, or differing opinions that can lead to any kind of conflict, disharmony, and abusive acts, either from among themselves or from the part of their adherents. They should play an exemplary role of models to the entire Ummah, in terms of mutual respect, love for each other, tolerance and brotherhood. Most importantly, they must consider that the protection and promotion of the well-being of the Deen and Ummah are far beyond any group or organizational interest they may belong to.

Islam began to reach shores of African countries right from the time of Umar bin Al-Khattab, (the 2nd caliph), when the Muslim forces led by several companions of the prophet, continued with the responsibility of expanding Islam to as many parts of the world as possible. The Muslim troops led by Uqbah bin Naufal was the one to introduce Islam in Africa. However, Islam reached West Africa in the 8th century A.D, during the period of the Umayyads caliphate, through commercial links that were established with North Africa (I, 1984).

There is no doubt that early Islamic scholars in Northern Nigeria over the period, had immensely contributed to eradicating ignorance and educating Ummah with sound Islamic Copyright (C) GLOBAL ACADEMIC EXCELLENCE (M) SDN BHD - All rights reserved 
knowledge both in theory and practice. In addition, the scholars made a concerted effort to unite the Ummah under one umbrella.

\section{Brief History of Islam in Northern Nigeria}

Islam emerged in the North-Eastern part of Nigeria around the 11th century. It is believed that the first to accept the religion of Islam in Nigeria was a Kanem-Borno ruler called Umme-Jilmi (1085-1097) (Oloyede, 2014), followed by his son Dunama I (1097-1150). In the 13th century, during the regime of Dunama II (1221-1256), a strong relationship had already been established between Kanem and Tunisia in Maghrib (Oloyede, 2014). By the 14th century, Kanem became a centre for teaching and learning of Islamic education. Traders and scholars then spread it to some parts of Hausa-land, such as Kano and Katsina.

In addition, Islam was brought by activities of Arab Traders crossing from North Africa through the Sahara Desert, up to the fringes of the Northern part of Nigeria. Kano city, Timbuktu in Mali and Agades in the Niger Republic were such very big markets forArabianTraders. Interaction with such Arab traders became a veritable way for the early introduction of Islam to the entire Hausa-land and other neighboring territories and communities of Northern Nigeria.

The summary of the History of Islam in Nigeria cannot be complete without mentioning the role of Usman bin Fodio, a famous and prominent Fulani scholar, who successfully launched a Jihad of reformation and expansion of Islam in the Northern part of Nigeria. Bin Fodio was born in Gobir in 1754, he received his Islamic education from various scholars and went to several places in search of knowledge. Whereat the age of 20 he had already become a wellknown scholar and preacher, with followership. In 1804 bin Fodio set a Jihad which lasted for about six years (Martin, 1976). The objective was to build a strong and solid foundation for the individual Muslim and progressive Muslim Umma, by way of reviving the Deen, by instilling its virtues in their minds, and established an administration guided by Islamic Shari'ah. The success recorded by bin Fodio led to the establishment of the most powerful social, political and economic system in the region of that time, i.e., "The Sokoto Caliphate". The system continued running peacefully and progressively, until 1903, when the invading the British army with superior firepower defeated the Caliphate, and incorporated it into the colony of Nigeria, thereby transforming Sultanate power to the British appointed high commissioner. Islam in Northern, as in other parts of Nigeria, continued to remain within the purview of the Ulama' and the traditional institutions with tacit supervision of the colonial masters. These arrangements continued after independence where the various administrative machinery of governance of the time, successfully substituted the role of the colonial master. It had been reported that bin Fodio, his family and students, wrote about 500 books, which all were in manuscript and highlighted several fields of Islamic knowledge. The books were written either in Arabic or in Hausa, where some little number was written in Fulfulde (Makau, 2017). It was the advent of colonial exploits that dismantle the arrangements of social, administrative, economic and legal institutions, established under the dynamic leadership of the Sokoto Caliphate. It is therefore not a coincidence that the Ulama' found it relevant in joining efforts by way of entrenching Islamic Movements and Organizations in addressing the issues arising from the fallout of the emerging dispensation under colonial rule. 


\section{Islamic Organizations in Nigeria}

It is no wonder that the establishment of Islamic organizations assume relevance. Even though, they have not replaced all that Sokoto Caliphate was to the Islamic religion and community, indeed they contributed in no small measure to the advancement of Islamic religion in Nigeria, and in fact, their dominance is also of significance in the challenges and prospect that is currently facing the Deen and the Ummah. For a proper understanding of the history of Islamic organizations in Nigeria, and especially on the role they currently assume on the Deen and Ummah, and also for better understanding, this paper categorizes the development of Islamic organizations into two main groups. The early Islamic Movement and the evolution of "Contemporary Formal Islamic Organizations".

\section{Islamic Movement and Their Contribution to Islam}

It is necessary to recognize that even before the coming of formal Islamic organizations, such as Jama'atu Nasrul Islam (JNI) there existed the Sufi Brotherhood not only in Nigeria but across the large spectrum of West-African Islamic communities. The emergence of the Sufi Brotherhood can be traced back to the early period of Islam in Nigeria and classified into two main groups i.e., the Qadiriyya and Tijjaniyya Islamic movement. All the two share identical ideologies deep- rooted in Sufism. The founder of Qadiriyya was Sheikh Abdul-Qadir Jeelani (1077-1166), from Gilan Bagdad. It was said that his origin traced back to Hassan and Hussain (R.A). The sons of Fatima (R.A), the daughter of the prophet, and finally to the prophet (PBUH). It is for this reason he holds a position of being "Qutb" (i.e., pole or axis), which became one of the Qadiriyya ideology that, believing in the Sheikh as a Gawth (Savior), and reciting his poem (al-Gawthiyyah) eleven times daily is considered to be beneficial for any adherent (Qadiriyya nd). Dhikr (Remembrance of Allah) is also part of its practices, but the dhikr is unlimited and not fix according to a specific rule (Ben Amara, 2013).

Tariqa al-Tijjaniyya, on the other hand, was also named after its founder Sheikh Ahmad Tijjani (1737-1815). He was from Algeria, also considered as one of the descendants of the prophet (PBUH), through his grandson Hassan (R.A). Sheikh Ahmad Tijjani studied in different places, which included among others, Fez, Morocco, Cairo, and Tunis. He spent the rest of his life in Fez, the place where he built his Zawiya (Sufi lodge). Tijjaniyya like Qadiriyya has many adherents, Senegal and Nigeria are among the places where they strongly practice Tijjaniyya. The followers of Tijjaniyya have been characterized by their asceticism, especially by their attachment to dhikr, which involves repetitive utterances of short sentences glorifying Allah. It includes the names of Allah or a supplication that has been taken from the Qur'an or Hadith. Among them are "La'ilaha Illal Lah" there is no god but Allah, "Astagfirul-Lah" I ask Allah for forgiveness and Salat for prophet Muhammad (PBUH). These three Adhkar are to be recited a hundred times morning and evening daily. Wazifa is another formula of Dhikr, that is chanted as a group, often at a mosque, or zawiya once daily, as well as the dhikr of al-Jumu'ah, Hailalat al- Jumu'ah, another formula chanted among other disciples on Friday afternoon before the sun sets down (Abun-Nasr, 2007).

Loimeier (2011), the Sufi Brotherhood of both Qadiriyya and Tijjaniyya have played a prominent role in spreading Islam in the northern part of Nigeria and providing guidance to Ummah of all ages. Ulamas of the Tariqa movement were responsible for the early establishment of Islamic teaching, training and preaching in Northern Nigeria, several generations before the advent of the colonial masters. The level of under-development at that time was so strong that anyone venturing in advancing the course of Islam must experience 
daunting sacrifices, in the effort to reach out in search of knowledge, or in its dissemination. This was exactly what they confronted and conquered. They left their homes, and traveled far distances in the foot, and at best on donkeys, to places far away from their villages and towns, foregoing full comfort and luxuries of their immediate families and communities. They were pioneers and founding fathers in the setting up, and establishment of the excellent Tsangaya Islamic educational system, which is today known as the "Almajiri system". The Almajiri system, though with its mounting problems, is generally misunderstood and misrepresented. Almajiri system is another topical issue, which is beyond the scope of this work, however, what has become obvious is the need for its reformation to reflect on the current realities facing it (Blake, 2019).

The task of converting Islamic scripts from full Arabic text to the various indigenous languages simplified the teaching and understanding of Islamic religion by several Northern Nigerian communities. Also, the conversion of the Arabic alphabets and vowels into Ajami accelerated the individual understanding of the Islamic concept and at the same time empowered him by his emancipation from the darkness of illiteracy. Since members of Ummah can now read and write in Ajami. This contribution by Tariqah Ulama, uplifted the educational standard of the individual Muslim in particular and the Islamic society in general, even before the arrival of the British with his so-called: "Western Education" (Ansari, 2018).

Despite their shortcomings, Tariqa Ulama' played fundamental, tough and difficult role of their times, in such a way that the fruit of the dent of their hard work is enjoyed by both contemporary students and scholars of Islam. This is evident in the fact that any scholar, either of Salafi or Izala was at one time a student of Tariqa teacher or has been taught by someone who himself was a student of Tariqa Ulama'. In addition, in their efforts to go with the tides of the present, many formal schools were established by Tariqa organizations, beginning from primary level, up to colleges, where diploma awards are obtainable (Sufism 2015). Nevertheless, like any human arrangement, there exist, within the Tariqa Movement, activities of a very few who lacked sufficient knowledge and understanding of Islamic teaching, or of others seeking for glorification, which tend to go far beyond the limits and bounds of fundamental Islamic norms and values. For example, the activity of this new emerging movement such as Fairah poses serious cause for concern, not only to the enlightened hardworking Ulamas of Sufi movement but to any adherent of the Deen of Islam. There is an urgent need for the entire Ummah to pay attention to the attitude of those overzealous few before it reaches a crescendo. In addition, the few Sufi's Ulama' that encourage their adherents into believing that they possessed supernatural powers beyond the basic Islamic norms, or of others who accord a position to the beloved prophet PBUH beyond what he and Allah SWT assigned to him, is counter to the teaching of Qur'an and Sunnah. As Allah SWT and his Prophet mention this severally and repeatedly in the

Qur'an and Sunnah:

\{The Jews say, "Ezra is the son of Allah". And the Christians say, "the Messiah is the son of Allah" that is their statement from their mouth: they imitate the saying of those who disbelieved [before them]. May Allah destroy them; how are they deluded? They have taken their scholars and monks as lords besides Allah. And [also] the Messiah, the son of Mary. And they were not commanded except to worship one God; there is no deity except Him. Exalted is He above whatever they associate with Him\}. (Qur'an 9: 30-31) 
\{And Muhammad (PBUH) is no more than a Messenger, and indeed many messengers have passed away before him...) (Qur'an 3:144).

The Prophet PBUH said: "Do not exceed the limits in dignifying me as the Christian have done to Jesus A.S. I am none but Allah's slave only and therefore you should call me a slave of Allah and His Messenger" (Reported by Bukhari and Muslim).

"I do not want you to raise me above the status which Allah has designated for me. I am Muhammad, the son of Abdullah, a slave of Allah and His Messenger" (Reported by Ahmad).

"Do not raise me any further than what my status is, because Allah has created me as His slave prior to appointing me as His Messenger”. (Reported by Al-Tabari)

\section{Formal Islamic Organizations in Nigeria}

Early political and traditional leaders, including Ulama and Adherents of the Deen of Islam in Nigeria, have at various times, been making efforts in the course of promoting the progress of the religion. One important of such advancement of the Deen is the creation of a platform that serves as an avenue for pulling individual efforts and resources for the course of progress of the Deen of Islam and the entire Ummah. The three main and pioneer groups were Ahmadiyya, Jama'atu Nasrul Islam and Muslim Students Society of Nigeria. These three groups were the root of all other organizations (i.e., Umbrella Islamic Organizations), such as the Nigerian Supreme Council for Islamic Affairs (NSCIA), Federation of Muslim Women Association of Nigeria (FORMWAN), and National Council of Muslim Youth Organizations (NACOMYO) (Sufism, 2015).

According to Ishaq (2015) the first formal Islamic organization established in Northern Nigeria after the amalgamation was Ansarul Islam Society of Nigeria, founded by Sheikhh Kamaluddeen al-Adabi in 1942, with the main goal of education. It was the first registered voluntary Islamic Organization to establish a primary school in Northern Nigeria, and it has many primary and secondary schools across Nigeria. On the prospects and challenges of these early Islamic organizations, a prominent Islamic scholar, outstanding academician of repute, professor S.A.S Galadanchi stated as follows:

"Nigeria gained her independence, the Northern Region...was lagging in terms of the Western system of education some of the political leaders realized they could not successfully rule without the support and cooperation of traditional rulers. Late Sardauna who served as the pivot around whom all other actors rotated was a political leader as well as a traditional ruler. He, therefore, instituted an Advisory Board on Religious Affairs with 100 members. The Board held its first meeting in August 1963 under the chairmanship of Waziri Junaidu of Sokoto. The achievement of the Advisory Board helped in uniting the Ulama and paving the way for the establishment of a non-governmental association which would serve as an umbrella for the entire Muslim Ummah in this country. Thus, using some of the members of the Advisory Board and some senior committed civil servants in his government, he was able to establish the Jama'tu Nasr al-Islam JNI. The inaugural meeting was held in Lugard Hall Kaduna, in March 1964 under the chairmanship of Dr. Waziri Junaidu of Sokoto. JNI began to grow until his death in 1966. JNI fell into slumber. Members attempted to draw the attention of the organization (to) its responsibilities. Those Young Turks saw no alternative but to set up their Muslim organizations"'(SAS, 2014). 
Could it be said that the inability of JNI (Jama'atul Nasarul Islam) to address that identifiable need confronting the Deen, was what gave rise to the emergence of young revolutionary "Turks"? Therefore, it can be deduced today that, realities of that "slumber" facing the Deen at that time were the basis for the strong reason for agitation of reformation. The inability to address squarely issues facing the Deen at the time, by those concerned, which also cannot be disassociated with the dominant chaotic socio-political issues that dominated the national landscape, especially after the 1964 general election and the subsequent unfortunate events that followed it, might have resulted for the inaction by JNI. Reformation by those unsatisfied "Turks" was the only alternative, despite the apparent thinking of the reasonable numbers for caution, and the need to avoid consequences of the fallout to the entire structure and unity of the Ummah and the Deen. Therefore, the reformist group insisted on pushing their doctrine of the Islamic teaching and belief, in the introduction of an approach that involves a literalist creed and a conviction that, every issue in contemporary human life can be resolved by consulting and applying the Qur'an and Sunnah, (model or tradition of the Prophet Muhammad (PBUH)), which was also the tradition set by the first three generations of Muslims. This Islamic doctrine is in total disagreement with ideologies of Sufism regarding a mystical approach to Islam, and to all others that share similar theological sects. For Izala, and later the Salafis, Salafism represents the pristine Islam of the early community.

\section{Izala and Salafi Movement}

What culminated in Salafism in Northern Nigeria today, started in the 1960s and 1970s with the moderate approach of SheikhAbubakar Gumi (1924-1992), who served as the north's top Islamic judge, from 1962-1966, and afterward became a prominent preacher of his time. Influenced by his stint with British colonial schools, and exposure to wider Islamic knowledge including further Islamic training in Sudan, coupled with his interaction in various engagements in the Middle Eastern countries, it is not surprising that Gumi saw the urgent need to championed the cause for reforming some ideology of suffist, especially in those areas where they go counter to the ideals and fundamental principles of Islamic teachings of Qur'an and Sunnah. Sheikh Gumi, though resolute but very moderate, and continuously guided by the need for caution, in a manner that no harm was done than good to the Deen and Ummah (Hunnalvatn, 2017). In 1978, more essential followers of Gumi formed the Society for the Removal of Heretical Innovation and the Establishment of the Sunna, better known as (Izalatul bid' ah wa-Iqamatus-Sunnah). Izala became a powerful movement, and a lot more forceful in disseminating anti-Sufism. It is to the credit of the Izala movement the revival of the pursuit of knowledge and reformation of Islamic social values that were diluted with cultural practices, that were not in accordance with Sunnah. Izala organized regular Da'awah (Wa'azi), at the ward, local government, state, and national levels. This organized approach to Da'awah not only brought entire membership under constant periodic interaction under one movement but also recorded a tremendous impact of enlightenment at all levels. In addition, so many schools from Ida'u right through to higher Islamic studies were set up all over the North. Islamic religious knowledge received a tremendous boost with the coming of Izala both at Schools and Masjids. In the same vein, observance of Islamic cultural values in conformity with the Sunnah was pursued vigorously. Men can easily be identified unlike in the past, with Islamic acceptable regalia, beards to correct shapes and sizes, whereas the women with a decent dressing that does not expose their features. Today, Hijab and Niqab are the common dressing for Muslim women in Northern Nigeria (Allman, 2004). 
However, Izala's uncompromising approach to the style of Da'awahto a community with a long-standing history of Islam and entrenched conservative cultural values, as that of the Northern part of Nigeria may never be readily acceptable. This has been worsened with the actions of overzealous few who disregarded the need for wisdom in Da'awah, as recommended by Allah SWT \{Call to the way of your Lord with wisdom and good preaching and practiced by the prophet PBUH, which is supposed to remain the template for any scholar engaged in Da'awah.

Nevertheless, there were tensions within Izala, particularly after Gumi died. In the 1990s, Izala split into two main factions, based respectively, in Kaduna and Jos as their headquarters. Even though there are ongoing attempts to reconcile the internal divisions, what is yet to be seen is whether such efforts can yield the desired goal of bringing the differing factions under one umbrella once again.

At the same time, young students who had studied at the Islamic University of Madina in Saudi Arabia and other Middle Eastern countries were returning home. Many of these returning graduates were upgrading and promoting the teaching approach of Izala. In the 1990s, some of these returning graduates began to present themselves as independent - as ahl al-sunna wa-1jama'a, "the people of the Sunna and the community," a synonym for Sunni Muslims. These returnee graduates wanted people to think of them not as mere Izala members but as the representatives of a pure kind of Sunni Muslims.

The prominent among Madina graduates was Sheikh Ja'far Mahmood Adam (1961/2-2007), who rose from a humble background to attain the status of the most famous reformist preacher in Northern Nigeria after Sheikh Gumi. After returning from Madina in 1993. Sheikh Ja'far promoted a scholarly approach to Salafi preaching. Indeed, he recorded a lot of successes, while differing in several respects from the apparent weaknesses in the style adopted by Izala. He was giving some responsibilities by the Kano State Government which some considered it politics. However, this cannot be correct, since the primary reason was his acceptance to head the Hisba Committee of the Kano State Government, at a time when the newly elected Governors of several Northern states declared the adoption of Shari'ah, in the advent of the third republic of the civilian administration after the 1999 general elections. Sheikh Ja'far realizing that the "so-called" Shari'ah lacked the required political will in its implementation, decided to resign from the service in 2005. This action by Sheikh Ja'far would have satisfied those that doubted his credentials for mere political considerations or pursuit. Unfortunately, most horrible event was the gruesome assassination of Sheikh Ja'far in 2007. This unfortunate controversial murder remained unresolved. When Ja'far's name is heard, it is often mentioned in connection to his mentorship of Muhammad Yusuf (1970-2009), the founder of Boko Haram (Alexander, 2016).

Muhammad \& Koki (2017) indicate there is no any connection between Ja' afar Mahmud Adam with founder of Boko Haram in terms of ideology of Boko Haram as some insist on relationship with Muhammad Yusuf. In order to do justice to Sheikh Ja'far and Salafis in general, the mentorship of Muhammad Yusuf as a student should go side-by-side with the history of the separated relationship that ensued between them. Sheik Ja'far persisted on his effort to call his student to order, and also for Yusuf to understand the fundamentals of Islamic teaching that go counter to his ideology. 
However, Adam's conflicts with Yusuf were a watershed moment for Salafism in Northern Nigeria. Yusuf took advantage of the networks and preaching style that Sheikh Ja'far Adam had developed. Yusuf sought to bend those resources to the unfortunate project of denouncing Western-style education and the secular government. Sheikh Ja'far fought back by attacking Yusuf with well-defined analytical facts that stood all the tests of Islamic teaching and values. SheikhJa'afar Adam also made the case for why preaching was better than armed jihad, and why Western-style education could benefit the Muslim community. But the story of mainstream Salafism in Northern Nigeria does not end with or revolve around the conflicts between Ja' far and Yusuf, or between mainstream Salafism and Boko Haram. Looking beyond Boko Haram, one finds that mainstream Salafis are making a lot of progress (Alexander, 2016).

Unlike in other countries, Nigeria's Izala and or Salafis have not formed a political party of their own. However, some individual capacities may be found in active politics. They even sometimes publicly support candidates for office and can be found on opposing parties, especially during electioneering activities. Some of them do hold government positions, both at state and national levels. Salafis are difficult to label on the scale of the "left-or-right" spectrum. They appear to be maintaining the balanced ground of blending social activism with humanitarian care for the most vulnerable members of society. For example, the mass wedding of divorcees and widows introduced by the Salafis is a project that has social coloration. Whereas, the effort of combining Da'awah with soliciting for charity in the establishment of centers for education, caring for the orphans, providing Ramadan feeding to the poor and other projects is modern in trending and progressive in nature (Thurson, 2016).

\section{Ulama of the Early Generation}

It has become imperative to step very backward, to understand, learn and take an example from the lives and practices of the early generation Ulama'. It is well known that Islam encouraged its followers to pursue knowledge. Likewise, teaching and learning are valuable pillars of all Muslim communities. In fact, we can say that Islam and the search of knowledge are inseparable aspects of human endeavor since the later deals practically with all issues of daily life, the former is the prerequisite for a believer to know and appreciate his Creator, Sustainer of all beings, and in the understanding of how to worship Him, including possessing the knowledge with which to examine and ponder on the creation of entire Universe, thereby discovering the evidence of Allah SWT in His uniqueness. Therefore, the importance of knowledge in Islam cannot be overemphasized. This is about the most important legacy and Sunnah of our beloved prophet PBUH bequeathed to the Sahabah and adherents of the Deen of Islam for all generations. No society can prosper without knowledge. Therefore, it is for this reason the early Islamic Scholars devoted their lives mainly in search of knowledge from all sources, regardless of creed, ideology, religion or culture, in so far as it can add value to the worship of Allah SWT, the Deen, and entire humanity.

Hasan (2009) The life of the founders of the four schools of fiqh and how they conducted and related to one another will continue to serve as an important lesson for all future Muslim generations. Imam Abu Hanifa, Imam Malik, Imam Shafi'i and Imam Ahmad, played significant roles in numerous fields of knowledge, more especially in Islamic Jurisprudence. Occasionally, they used to arrive at a consensus on a subject matter while disputed on several others. They never considered their differences in opinion to mean misinterpretation of the Qur'an and Sunnah, neither did they want to bring confusion in the minds of the Muslims, as many tend to portray. Rather, their differences are mainly centered around the Fru'at 
(branches), not the Usool (the sources). Despite such overwhelming differences on certain matters, they remain brothers and friends. The love and respect accorded one another by these jurists were so great. They always come together in order to dwell and discuss all issues of religious relevance, including areas where they differ. They did with utmost understanding and respect for each other's position, and always admonish their students and Ummah to demonstrate such attitudes in their collective and individual relationships.

Imam Abu Hanifa used to visit the (lesson)Majalisof Imam Malik despite the fact that he is about thirteen years older than him. While Imam Malik would respectfully welcome and seats next to him(A,1984). Imam Abu Hanifa and Imam Malik were students of Imam Muhammad bin Shihab al-Zuhri on Hadith. They also learned from Imam Ja'far al-Siddiq (d. 198 A.H). Likewise, the famous Tabi'i Scholar Muhammad bin al-Munkadir al-Madani (d. 131 A.H) was also their teacher. Vice-versa, Imam al-Zuhri, the teacher of Imam Malik did not hesitate to also learn from his student Malik. So also, the famous student of Imam Abu Hanifah, Imam Muhammad bin al-Hassan went to Madinah and learned Muwatta from Imam Malik. Imam Shafi'i also learned Hadith from Imam Malik, and when he was asked about his teacher, he said: "If Imam Malik and Sufyan bin Uyaynah were not around, there would not be the existence of the science of Hadith in Hijaz". He also said in the book of Hadith (al-MuwattaMalik): "There has never appeared on earth a book that is closets to the Qur'an than the book of Malik" (A, 1984). That was how those famous scholars treated each other with respect, love, and understanding. They are those Ulama' that Muslims today considered their jurisprudential teachings as respectful madhahibs.

Another relevant example was the essential contributions made by early Islamic Scholars in different fields of knowledge, such as; Philosophy, Mathematics, Astronomy, Medicine, Geography, Arts and Literature, etc. Indeed, many European intellectual achievements were founded on the work of early Muslims scholars. One of the valuable contributions of Muslim scholars was the translation into Arabic of works by scientists and philosophers of ancient Greece. During early Abbasid rule much of this work took place at an academy in Baghdad called 'Daar Al-Hikmah', i.e., the House of Wisdom which was maintained by the Islamic government of the time. Through their translations, the resident scholars made texts from Hippocrates, Euclid, Galen, and Ptolemy, which were made available to the new audience for further study. Once translated into Arabic, the Greek texts stimulated further study throughout the Muslim world. The influence of these texts extended to Europe. The Arabic versions of many works were eventually translated into Latin. It was in this manner fields of knowledge emerged and became available to European scholars and developed to what is seen and regarded as western knowledge. In fact, much of this scientific and philosophical thought in European universities during the Middle-Ages came from such translations. Muslim Spain i.e., Andalus was the exchange point for much of this knowledge. For example, a Muslim scholar of Cordoba, Spain, named Ibn Rushd or Averroes wrote commentaries on Aristotle. Ibn Rushd's work on the relationship between reason and faith, which played immense influence, not only on Muslim but also Jewish and Christian thinking into the 1400s and beyond (Ramirez, Stearns \& Wineburg 1998).

\section{The Contemporary Ulama'}

The first generation Ulama' and many subsequent that followed, have left an excellent role model of what an average Islamic scholar shall be, not only as an individual, but also an as significant body of a learned group that is united in purpose and complimentary in the overall 
task of discharging his duties to uplift the Deen, and for the progress, growth, and development of the Ummah and the individual Muslims. This is the legacy that the present Ulama' of Northern Nigeria should emulate and put into practice.

Presently, though there are several hardworking Islamic Scholars that should be commended and would make generalizations impossible, however, the fact still remains that several give more emphasis to the advancement of group interest of their respective movements. After all Allah SWT says \{Verily, those who divide their religion and break up into sects (all kinds of religious sects), you (O Muhammad (Peace and blessings be upon him) have no concern in them in the least.\} (Qur'an 6: 159).

Despite full knowledge of these divine warnings, it is not uncommon for some Ulama' to venture into highly divisive Da'wah that directly offend the other, and unfortunately on an issue that is not even of significance. No matter the significance, cognizance of two important issues should be taken into consideration. Firstly, Allah SWT said:

\{Invite to the way of your Lord with wisdom and good instruction and argue with them in a way that is best. Indeed, your Lord is the most knowing of who has strayed from His way, and He most knowing of who is [rightly] guided) (Qur'an 16: 125).

Secondly, the level of knowledge and understanding of the average receiver of the call, majority of them in Northern part of our country, lack deeper knowledge to enable them to comprehend, are therefore left confused, and at worst also left with the re-enforcement of their earlier understanding of the wrong teachings that are intended to be corrected. In addition, Prophet Muhammad PBUH left "no stone unturned" on working towards the promotion of a united common brotherhood of companions. In Madinah, he ensured the emergence of Ummah, whose hearts were full of mutual love and deep respect and care for one another. That dedicated effort by prophet PBUH, resulted on a very strong united companionship of followers with deep Imaan and commitment to the overall objective of Ummah and the Deen of Islam, to the extent that out of fractured tribes of Madinah (Ansaar) and the visiting Muhajirun from Macca, there appeared unparalleled community (of Sahabah) that Allah SWT mentioned as the best generally among the Muslim nations, and shall remain so on the face of the globe. Allah SWT says:

$\{$ You are the best nation produced (as an example) for mankind. You enjoin what is right and forbid what is wrong and believe in Allah\} (Qur'an 3: 110)

The saying of the Prophet PBUH should be heeded in the following Hadith: "...O servant of Allah be brothers" (Reported by Bukhari, Muslim, and Abu Dawood). Abu Hurairah, may Allah be pleased with him, narrated that the Messenger of Allah, peace, and blessings be upon him, said, "The Jews were split up into seventy-one (or seventy-two sects), and the same is true of the Christians. As for my nation, it will be split up into seventy-three sects" (Reported by Ahmad, Abu Dawud, At-Tirmidhi, and Ibn Majah).

In addition, Allah SWT warned: "Surely you have nothing to do with those who have made divisions in their religion and become factions. Their matter is with Allah and He will indeed tell them (in time) what they have been doing." (Qur'an 6: 159). 
Therefore, should it not be the pre-occupation of the Ulama' in the North, with the contemporary problems and challenges facing the Deen and Ummah, and work towards providing possible solutions to them in accordance with the teaching of Islamic values? On this regard the prominent Islamic Caliph Al-sheik Usman bin Fodio saying cannot be more relevant:

"Busy yourselves, then, oh my brethren by reading the literary works (written) by scholars of your time. This is because they know those things that are important to your time and situation. It has become part of their (scholars) effort to give details of those things (that are important to your situation but) given briefly in books of previous scholars. Hence the works of each generation serve as an additional explanation to the literary works of those who preceded them. For this reason, each scholar (in every period) exerted effort and busied himself with authorship on his own, notwithstanding, that all that which could satisfy people's need in matters of religion were available in the books of the scholars before him (but to update Muslims and keep them informed of the contemporary developments)Bunza (2014).

\section{The Virtue of Unity and Negative Impact of Disunity among Muslim Ummah}

Today, like in so many other Muslim societies, the disparities among Ummah, arising from the activities of some Ulama' of different movements and organization they belong, does not augur well to the general growth, peaceful progress of Islamic religion in Northern Nigeria. In fact, it appears as the major leading obstacle in the well-being and progress of the Ummah. Other problems include; sectarianism, extremism, hatred, lack of mutual respect and understanding among some Ulama and their students of different groups, movements or sects. These and so many other problems confronting the Deen and Ummah are results of disunity and in turning away from the commandment of Allah and His Prophet (PBUH). Al-Sheikh Ali Ibn AbdurRahman al-Hudhaifi said in his Khutba:

"Disagreement and disunity cause a great deal of harm to the Muslim nation in their religion and interests. They weaken their power and sow the seeds of discord among its members. Differences obscure the truth such that it is not revealed to everyone; the truth may be perceived as falsehood and falsehood may be perceived as truth" (Al-Hudhaifi, 1434)

Unity, as oneness, and the state of being undivided may be seen as "mirage" and too difficult to achieve by the Muslim Ummah, not only in Northern Nigeria but in so many Islamic communities all over the world. However, it should be noted that there is no achievement for any group of people, entity or nation that has no unity among themselves. (Yasin and Dahalan 2012) defined unity of an entity of society as the situation whereby ethnic group, religious group and people from different locations live in harmony (Yassin \& Dahala (2012). They also mentioned that:

"No society can develop beyond its unity, towards achieving its goals and objectives. Solely, unity, harmony, accord and solidarity among the members and make their society able to function justly and further reinforce it toward progress; and, vice versa, disunity, discord, and antagonism".

In an article entitled The Voice of Truth Nursi defined the goal of unity as follows: "The aim and goal of unity are to stir into life the long, many-branched, far-reaching luminous chain which binds together the centres of Islam and their places of worship, to arouse those bounds 
to it, and through the wishes and promptings of their consciences drive them to the way of progress" (Nursi 2002).

However, Islam as a religion enjoins Muslim Ummah to remain united as one family without division. Allah has mentioned in the Holy Qur'an:

"And hold firmly to the rope of Allah together and do not become divided" (Qur'an 3: 103). "And do not be like ones who became divided and differed after the clear proofs had come to them" (Qur'an 3: 105)

\section{Conclusion}

The best gift that Allah SWT bestowed upon a human being is "the wisdom of knowledge", it is the most precious and valuable honor that distinguishes man from other creations. Indeed, the Angels expressed their jealousy when Allah informed them of His intention of creating a man as His vicegerent on earth as revealed in Surah al-Baqarah verse 30-33. Therefore, the best among nations are those who have taqwa (fear of Allah), and those who have taqwa are those who have knowledge. That is what Allah SWT said in the glorious Qur'an. He mentioned:

\{Only those who fear Allah, among His servants, who have knowledge\} (Qur'an 35: 28).

This underscores the virtue and importance of the exalted position of scholars among the Muslim community. As they become the best people of the nation, they are also the Auliya', those that undertake the task of reviving the Deen and providing Islamic solutions (Islah) to their communities. Therefore, Muslim society is that which always subject itself to the direction of its Ulama' in all its affairs. In the same vein, spiritual guidance, general growth and development of Islamic Ummah is defendant upon the disposition and commitment of its Ulama'. The three Qur'anic verses of Surah Al-Imran verse 137-139 via witness to the rise and fall of the earliest generations.

Evidently, this paper has recognized and supported by relevant facts the important roles played by both early and contemporary Ulama' of Northern part of Nigeria, on the progress and development of the Deen of Islam and its Ummah. In fact, the Muslims of many generations to come shall benefit from the immense contributions of those Ulama', of Tariqa, Izala, and Salafi, in their attempt to eradicate the darkness of ignorance, and bring in its place the light inherent in the Deen of Islam. Nevertheless, despite these overwhelming efforts, there are still associated challenges that have a great impact on the development of the Deen and Ummah. The challenge before the contemporary Ummah was how to address the distortion of the basic Islamic teaching of bringing the Ummah, under one uniting religious belief of worshiping none but Allah SWT, as taught by the seal of His messengers, Prophet Muhammad PBUH, thereby emancipating the ordinary adherent from the consequences of the dis-unifying factor, and its effect that left him lagging behind, at this critical time of rapid socio-economic, scientific and technological changes that is taking place, not only in Nigeria but all over the world.

\section{Recommendations:}

i. Unity and solidarity among Ummah played a significant role in the emergence and success of the Islamic religion. To succeed in their duties to Allah SWT, for the society to restore its glorious status of the past, they must close ranks, become more tolerant of each other and united in purpose in their divine leadership positions. 
Allah (SWT) said: \{The believers are but a single Brotherhood. So, make peace and reconciliation between your two contending brothers, and observe your duty to Allah, that you may receive mercy\} (Qur'an, 49:10-11).

ii. Divine guidance from the Qur'an and Sunnah must remain the focal point. Any contending issue or difference in opinion and or of interpretation should be resolved and accepted, where contention is supported by relevant evidence of the Qur'an and Sunnah, and therefore, should not be a cause for division. As the Prophet PBUH said, but in a weak Hadith "Differing opinion in my Ummah is a blessing".

iii. Establishment of a common platform that shall bring together, Ulama' of both Qadiriyya, Tijjaniyya, Izala, and Salaf should be considered. This is with the main object of bringing the entire Ummah together, set out a common vision that shall address the yearning and aspirations of the Muslims, by harnessing resources and efforts towards the realization of the achievement of a common goal, for the growth and development of Islam in general and the individual Muslim in particular, (both in terms of religious, economic, social, scientific and technological developments).

iv. Inculcation of brotherhood, acceptable moral values of love and respect for one another, and above all, the fear of Allah SWT shall be the guiding principle of any scholar in discharging his onerous task and duties of being the representative and inheritor of the beloved prophet PBUH.

\section{References}

A (1984), Shari'ah: the Islamic Law, A.S. NOORDEEN, Kuala Lumpur, Malaysia, p. 87

Abun-Nasr, J. M. (2007). Muslim communities of grace: the Sufi brotherhoods in Islamic religious life. Columbia University Press.

Akhmetova E. (2015). Unity of Muslims as a Prerequisite for Successful Islamic Civilisation: Risale-I Nur's Approach.International Conference On Empowering Islamic Civilization in The 21st Century. P, 85.

Allman, J. M. (Ed.). (2004). Fashioning Africa: power and the politics of dress. Indiana University Press.

Ansari, H. (2018). " The infidel within": Muslims in Britain since 1800. Oxford University Press.

B.G. Martin (1976). Muslim Brotherhood in Nineteenth Century Africa, Cambridge University Press.

Ben Amara, R. (2013). The Izala Movement in Nigeria: Its Split, Relationship to Sufis and Perception of Sharī'a Re-Implementation (Doctoral dissertation).

Blake, B. (2019). The Experience of Urban Northern Nigerian Malamai Who Facilitate Vocational Education for Their Urban Northern Nigerian Almajirai (Doctoral dissertation, Capella University).

Bunza M.U. (2014). The New Role of Ulama in Nigeria. Al-Jāmi'ah: Journal of Islamic Studies, 52 (2), 394-395

Hasan, N. (2009). Islamizing formal education: Integrated Islamic school and a new trend in formal education institution in Indonesia.

https://www.google.com/amp/s/navigatingnigeria.wordpress.com/2015/04/06/sufi sm-innigeria/amp/ 
Hunnålvatn, H. H. H. (2017). Going inside the" haze of dust": The emergence of Boko Haram 2002-2009 (Master's thesis).

I.A, (1984) Islam in Nigeria, Gaskiya Corporation limited, Zaria p.7

Is-haq, O. O. (2015). Islam in Nigeria: A Century of National Islamic Societies. Journal of Islam in Nigeria, 1(1), 1.

K. Makau (2017). Islamic Scholarship and Scholars in Modern Nigeria 1900-Date.Being a lead paper presented at a conference on Islamic Scholarship and Scholars in Modern Nigeria. Organized by Department of Islamic Studies and Shari'ah, Bayero University Kano

Loimeier, R. (2011). Islamic reform and political change in northern Nigeria. Northwestern University Press.

Nu'aym, A. (1405 H.). Hilyat al-Awliya'. Dar al-Kitab al-Arabi, Beirut, Vol. 4. 4th edition

Oloyede I. (2014). Islam in Nigeria: A century of National Islamic Societies. Keynote address presented at the International Conference of Islam in Nigeria (COIN). pp. 5-6

Qadiriyya https://en.wikipedia.org/wiki/Main_Page

Ramirez S. Stearns P. Wineburg S. (1998). Human Legacy. Holt, Rinehart and Winston Austin, Texas. Pp 271-272

S.A.S. Galadanci (2014): Nigerian Muslims and the JNI: Strengths, achievements, Prospects, and Challenges an unpublished paper delivered at the JNI 50th Public Annual Lecture on the 13th of April, 2014 pp5\&7

Sheikh Ali ibn Abdur-Rahman Al-Hudhaifi 20 Thul Hijjah 1434http://radioislam.org.za Sufism in Nigeria

T. Alexander (2016). Salafism in Nigeria Islam, Preaching and Politics. International African Institute, London and Cambridge University Press. Pp. 193-195

Thurston, A. (2016). Salafism in Nigeria: Islam, preaching, and politics (Vol. 52). Cambridge University Press.

Yassin, S. M. \& Dahalan, D. (2012). Unity concept from the Islamic perspective and reality of unity in Malaysia. Research on Human and Social Sciences, 4 (2), 66-83. form www.iiste.org 